\title{
PENGARUH RELATIONSHIP QUALITY TERHADAP LOYALITAS NASABAH TABUNGAN TAPLUS PADA PT. BANK NEGARA INDONESIA (PERSERO) TBK CABANG RENGAT
}

\author{
Joe Vandra, Aminar Sutra Dewi \\ Sekolah Tinggi Ilmu Ekonomi KBP \\ joevandra18@gmail.com
}

\begin{abstract}
The purpose of this research is to analyze the influence of trust, satisfaction, and commitment to customer loyalty of Taplus savings at PT. Bank Negara Indonesia (Persero) Tbk Branch Rengat. Population in this research is all customer of Taplus at PT. Bank BNI Branch Rengat Riau which amounted to 15,173 people. The sampling technique used is random sampling, while the number of samples used for the analysis is 100 people. Data analysis techniques used to test the hypothesis is multiple linear regression. As for hypothesis testing using statistical $t$ test. The results showed that the variable of trust does not have influence on customer loyalty of Taplus savings at PT. Bank Negara Indonesia (Persero) Tbk Branch Rengat. While the variable satisfaction and commitment have a significant influence on the loyalty of customers of Taplus savings at PT. Bank Negara Indonesia (Persero) Tbk Branch Rengat.
\end{abstract}

Keywords: Trust, Satisfaction, Commitment, and Customer Loyalty

\section{PENDAHULUAN}

Penelitian ini dilatarbelakangi oleh fenomena persaingan di industri perbankan guna memperoleh loyalitas nasabah. Cukup banyaknya bank-bank khususnya di daerah Rengat Riau ini, membuat PT. Bank BNI Cabang Rengat Riau perlu memper tahankan dan meningkatkan strategi baru guna menjaga nasabah nya untuk tetap loyal bahkan menambah jumlah nasabahnya. PT. Bank BNI Cabang Rengat Riau harus dapat memuaskan nasabah lama dan menciptakan nasabah baru, jika ingin memenang kan persaingan dan menjadi market leader dalam industri perbankan khususnya di daerah Rengat Riau. Terlihat bahwa beberapa tahun belakangan ini PT. Bank BNI Cabang Rengat Riau mengalami fluktuasi jumlah nasabah.

Berdasarkan data yang dipero leh dapat diketahui perkembang an jumlah nasabah tabungan pada PT. Bank BNI Cabang Rengat Riau. Berdasarkan tabel dapat dilihat jumlah nasabah mengalami peningkat an tiap tahunnya, tapi pada tahun 2015 jumlah nasabah tabungan taplus pada bank BNI Cabang Rengat Riau mengalami penurunan yang signifikan sebesar 32\%. Hal ini memberikan indikasi bahwa loyalitas nasabah menabung di PT. Bank BNI Cabang Rengat Riau menjadi hal yang menarik untuk di teliti. 
Salah satu cara yang dilaku kan oleh PT. Bank BNI Cabang Rengat Riau dalam usaha memper tahankan loyalitas nasabahnya adalah dengan tetap membina kualitas hubungan (relationship quality) yang baik dengan setiap nasabah. Hubungan ini sendiri dapat dikatakan sebagai suatu program dalam mencapai loyalitas nasabah, dimana nasabah diajak untuk membangun suatu hubungan yang lebih dekat dengan menciptakan komunikasi dua arah sehingga dapat menimbulkan kepercayaan, kepuasan, bahkan sebuah ikatan sosial yang pada akhirnya dapat menimbulkan sebuah komitmen antara nasabah dan perusahaan perbankan.

Rumusan Masalah

1. Bagaimana pengaruh kepercaya an terhadap loyalitas nasabah tabungan Taplus pada PT. Bank Negara Indonesia (Persero) Tbk Cabang Rengat?

2. Bagaimana pengaruh kepuasan terhadap loyalitas nasabah tabungan Taplus pada PT. Bank Negara Indonesia (Persero) Tbk Cabang Rengat?

3. Bagaimana pengaruh komitmen terhadap loyalitas nasabah tabungan Taplus pada PT. Bank Negara Indonesia (Persero) Tbk Cabang Rengat?

\section{LANDASAN TEORI}

\section{Loyalitas Pelanggan}

\section{Pengertian Loyalitas Pelanggan}

Menurut Griffin (2003:31), pelanggan berasal dari kata custom yaitu didefinisikan sebagai membuat sesuatu menjadi kebiasaan atau biasa dan mempraktekkan kebiasaan. Selanjutnya Griffin berpendapat bahwa seseorang pelanggan dikatakan setia atau loyal apabila pelanggan tersebut menunjukkan perilaku pembelian secara teratur atau terdapat suatu kondisi dimana mewajibkan pelanggan membeli paling sedikit dua kali dalam selang waktu tertentu. Upaya memberikan kepuasan pelang gan dilakukan untuk mempengaruhi sikap pelanggan, sedangkan konsep loyalitas pelanggan lebih berkaitan dengan perilaku pelanggan dari pada sikap dari pelanggan.

\section{Kepercayaan}

\section{Pengertian Kepercayaan}

Kepercayaan konsumen menurut Mowen dan Minor (2002:312) adalah semua pengeta huan yang dimiliki oleh konsumen dan semua kesimpulan yang dibuat konsumen tentang objek, atribut, dan manfaatnya.

\section{Kepuasan}

\section{Pengertian Kepuasan}

Menurut Kotler dan Keller (2009:14) kepuasan mencerminkan penilaian seseorang tentang kinerja produk anggapannya atau hasil kaitannya dalam ekspektasi. Jika kinerja produk tersebut tidak memenuhi ekspektasi, pelanggan tersebut tidak puas dan kecewa. Jika kinerja produk sesuai dengan ekspektasi, pelanggan tersebut puas. Jika kinerja produk melebihi ekspektasi, pelanggan tersebut senang.

\section{Komitmen \\ Pengertian Komitmen}

Barnes (2003:150) menyata kan bahwa komitmen adalah suatu keadaan psikologis yang secara global mewakili pengalaman ketergantungan pada suatu 
hubungan; komitmen meringkas pengalaman ketergantung an sebelumnya dan mengarahkan reaksi pada situasi baru.

\section{Hipotesis}

1. Diduga kepercayaan berpengaruh signifikan dan positif terhadap loyalitas nasabah tabungan Taplus pada PT. Bank Negara Indonesia (Persero) Tbk Cabang Rengat.

2. Diduga kepuasan berpengaruh signifikan dan positif terhadap loyalitas nasabah tabungan Taplus pada PT. Bank Negara Indonesia (Persero) Tbk Cabang Rengat.

3. Diduga komitmen berpengaruh signifikan dan positif terhadap loyalitas nasabah tabungan Taplus pada PT. Bank Negara Indonesia (Persero) Tbk Cabang Rengat.

\section{METODE PENELITIAN}

\section{Populasi dan Sampel}

Di dalam penelitian ini yang menjadi populasi adalah seluruh nasabah tabungan Taplus PT. Bank BNI Cabang Rengat Riau yang berjumlah 15.173 orang.

Melalui perhitungan dengan menggunakan rumus slovin maka jumlah responden sebagai sampel dalam penelitian ini adalah sebanyak 100 orang. Dalam penelitian ini teknik penarikan sampel yang digunakan adalah metode random sampling, yaitu pengambilan sampel secara acak.

\section{Uji Validitas}

Uji validitas digunakan untuk menguji seberapa cermat suatu alat ukur dalam melakukan fungsi ukurannya. Bila nilai corrected item to total correlation suatu butir pernyataan lebih besar dari 0,30 maka butir pernyataan tersebut dinyatakan valid, dan bila nilai corrected item to total correlation lebih kecil dari 0,30 , maka butir pernyataan tersebut dinyatkan tidak valid. Butir pernyataan yang dinyatakan tidak valid akan dikeluarkan atau tidak digunakan mengukur sebuah variabel penelitian (Sugiyono, 2013:209).

\section{Uji Reliabilitas}

Uji reliabilitas dilakukan terhadap pertanyaan yang telah valid. Rumus yang dipakai adalah untuk menguji reliabilitas dalam penelitian adalah Cronbach' Alpha. Semakin dekat koefisien keandalan dengan 1,0 semakin baik. Secara umum keandalan kurang dari 0,60 dianngap buruk, keandalan dalam kisaran 0,70 bisa diterima, dan lebih dari 0,80 adalah baik (Sekaran, 2006:182).

\section{Analisis Deskriptif}

Analisis deskriptif adalah transformasi data mentah ke dalam bentuk yang mudah dipahami atau diinterprestasikan. Bertujuan untuk memperoleh gambaran obyektif mengenai obyek penelitian.

\section{Uji Asumsi Klasik}

Uji Normalitas

Menurut Ghozali (2011:160-163) didalam melakukan pengujian normalitas digunakan alat uji non parametric One Sample Kolmogorov Smirnov Test. Didalam pengujian data normalnya sebuah variabel ditentukan dari nilai asymp sig > alpha 0,05. 


\section{Uji Heteroskedastisitas}

Heteros kedastisitas dengan uji Glejser tidak terjadi apabila tidak satupun variabel independen signifikan secara statistik mempenga ruhi variabel nilai absolute Us (AbsUt). Hal ini dapat dilihat dari nilai signifikansinya di atas tingkat kepercayaan $5 \%(0,05)$. Jadi dapat disimpulkan model regresi tidak mengandung adanya Heteroskedas tisitas.

\section{Uji Multikolinieritas}

Pengujian ini dilakukan untuk melihat apakah pada model regresi ditemukan adanya korelasi antar variabel independen. Jika terjadi korelasi yang kuat, maka dapat dikatakan telah terjadi masalah multikolinearitas dalam model regresi. (Umar, 2013:177) menyata kan pedoman suatu model regresi yang bebas multikolinearitas adalah:

1. Mempunyai nilai VIF (Variance Influence Faktor) lebih kecil dari 10.

2. Mempunyai angka Tolerance lebih besar dari 0,10.

\section{Analisis Regresi Linier Berganda}

Persamaan regresi linier sederhana adalah:

Di mana:

$$
Y=\alpha+\beta_{1} X_{1}+\beta_{2} X_{2}+\beta_{3} X_{3}
$$

$\mathrm{Y}=$ Loyalitas Nasabah

$\mathrm{a}=$ Konstanta

$\beta_{1}=$ Koefisien Regresi Kepuasan

$\beta_{2}=$ Koefisien Regresi Kepercayaan

$\beta_{3}=$ Koefisien Regresi Komitmen

$\mathrm{X}_{1}=$ Kepuasan

$\mathrm{X}_{2}=$ Kepercayaan

$\mathrm{X}_{3}=$ Komitmen

\section{Pengujian Hipotesis}

\section{Uji F Statistik}

Uji F yaitu suatu uji untuk mengetahui seberapa besar pengaruh variabel bebas (X) secara bersama-sama (simultan) terhadap variabel terikat (Y). Bisa dilihat dari probabilitas variabel bebas disbanding kan dengan tingkat kesalahannya, dengan menggunakan angka probabilitas signifikasi:

1. Jika nilai Sig. atau signifikansi $<\alpha$, maka terdapat pengaruh yang signifikan dari variabel bebas terhadap variabel terikat secara bersama-sama.

2. Jika nilai Sig. atau signifikansi $>\alpha$, maka tidak terdapat pengaruh yang signifikan dari variabel bebas terhadap variabel terikat secara bersama-sama.

\section{Uji t Statistik}

Untuk melihat tingkat signifikan di masing-masing variabel independen secara statistik, dan digunakan untuk mengetahui pengaruh signifikan variabel independen terhadap variabel dependen secara individu atau parsial. Untuk membuktikan pengaruh variabel independen terhadap variabel dependen secara parsial atau individu. Bisa dilihat dari probabilitas variabel bebas dibandingkan dengan tingkat kesalahannya, dengan menggunakan angka probabilitas signifikansi: 
1. Apabila nilai signifikasi $>0,05$, maka $\mathrm{H}_{0}$ diterima dan $\mathrm{H}_{\mathrm{a}}$ ditolak. Artinya variabel independen secara individual tidak berpengaruh signifikan terhadap variabel dependen.

2. Apabila nilai signifikasi $<0,05$, maka $\mathrm{H}_{0}$ ditolak dan $\mathrm{H}_{\mathrm{a}}$ diterima. Artinya variabel independen secara individual berpengaruh signifikan terhadap variable dependen.

\section{Uji Koefisien Determinasi $\left(\mathbf{R}^{2}\right)$}

Uji koefisien determinasi $\left(\mathrm{R}^{2}\right)$ digunakan untuk mengukur seberapa jauh kemampuan model dalam menerangkan variasi variabel dependen. Nilai $R^{2}$ yang semakin mendekati 1 , berarti variabel-variabel independen memberikan hampir semua informasi yang dibutuhkan untuk memprediksi variasi variabel independen. Koefisien determinasi yang digunakan adalah nilai Adjusted $R$ Square karena lebih dapat dipercaya dalam mengevaluasi model regresi.

\section{HASIL PENELITIAN DAN PEMBAHASAN \\ Uji Validitas}

Hasil uji validitas pada 4 variabel penelitian tersebut dapat dilihat pada Tabel 1 berikut:

\section{Tabel 1}

\section{Hasil Pengujian Validitas}

\begin{tabular}{|l|c|c|c|}
\hline \multicolumn{1}{|c|}{ Variabel } & Jumlah Item & Nilai Kritis & Kesimpulan \\
\hline Kepercayaan $\left(\mathrm{X}_{1}\right)$ & 4 & 0,30 & Valid \\
\hline Kepuasan $\left(\mathrm{X}_{2}\right)$ & 5 & 0,30 & Valid \\
\hline Komitmen $\left(\mathrm{X}_{2}\right)$ & 5 & 0,30 & Valid \\
\hline Loyalitas Nasabah $(\mathrm{Y})$ & 5 & 0,30 & Valid \\
\hline
\end{tabular}

Sumber: Olahan Data SPSS 2017.

Dari Tabel 1 dapat dilihat dari hasil pengolahan data, bahwa dari 4 varibel dalam mengukur item pernyataan memiliki nilai corrected item to total correlation lebih besar dari nilai kritis, yaitu 0,30. Dengan demikian dapat disimpulkan bahwa 4 varibel dalam mengukur item pernyataan tersebut adalah valid.

\section{Uji Reliabilitas}

Dari proses pengujian reliabilitas yang telah dilakukan diperoleh ringkasan hasil seperti yang terlihat pada Tabel 2 berikut ini:

\section{Tabel 2}

Hasil Pengujian Reliabilitas

\begin{tabular}{|l|c|c|c|}
\hline \multicolumn{1}{|c|}{ Variabel } & $\begin{array}{c}\text { Cronbach's } \\
\text { alpha }\end{array}$ & Nilai Kritis & Kesimpulan \\
\hline Kepercayaan $\left(\mathrm{X}_{1}\right)$ & 0,657 & 0,60 & Reliabel baik \\
\hline Kepuasan $\left(\mathrm{X}_{2}\right)$ & 0,679 & 0,60 & Reliabel baik \\
\hline Komitmen $\left(\mathrm{X}_{2}\right)$ & 0,665 & 0,60 & Reliabel baik \\
\hline Loyalitas Nasabah $(\mathrm{Y})$ & 0,676 & 0,60 & Reliabel baik \\
\hline
\end{tabular}

Sumber: Olahan Data SPSS 2017. 
Berdasarkan Tabel 2 dapat dilihat dari hasil pengolahan data bahwa ternyata nilai Cronbach's alpha untuk ke empat variabel nilai Cronbach's alpha nya $>0,60$. Maka dapat disimpulkan bahwa butir pernyataan yang valid tersebut handal, sehingga tahapan pengolahan data selanjutnya dapat dilakukan.

\section{Analisa Deskriptif} penelitian.

Pada sub bab ini diuraikan tentang deskripsi masing-masing variabel

Tabel 3

Hasil Analisa Deskriptif

\begin{tabular}{|l|c|c|c|}
\hline \multicolumn{1}{|c|}{ Variabel } & Skor Rata-Rata & TCR & Kategori \\
\hline Kepercayaan $\left(\mathrm{X}_{1}\right)$ & 3,42 & 68,4 & Cukup Tinggi \\
\hline Kepuasan $\left(\mathrm{X}_{2}\right)$ & 3,10 & 62,0 & Kurang Puas \\
\hline Komitmen $\left(\mathrm{X}_{2}\right)$ & 3,08 & 61,6 & Kurang Baik \\
\hline Loyalitas Nasabah $(\mathrm{Y})$ & 3,09 & 61,9 & Kurang loyal \\
\hline
\end{tabular}

Sumber: Olahan Data SPSS 2017.

Berdasarkan Tabel 3 dapat diketahui bahwa rata-rata variabel kepercayaan adalah 3,42 dengan TCR sebesar 68,4\%. Hal ini bermakna bahwa kepercayaan nasabah termasuk ke dalam kategori cukup tinggi. Untuk rata-rata variabel kepuasan adalah 3,10 dengan TCR sebesar 62,0\%. Hal ini bermakna bahwa kepuasan nasabah termasuk ke dalam kategori kurang puas. Sealanjutnya untuk rata-rata variabel komitmen adalah 3,08 dengan TCR sebesar 61,6\%. Hal ini bermakna bahwa komitmen termasuk ke dalam kategori kurang baik. Ratarata variabel loyalitas nasabah adalah 3,09 dengan TCR sebesar 61,9\%. Hal ini bermakna bahwa loyalitas nasabah termasuk ke dalam kategori kurang loyal.

\section{Uji Asumsi Klasik}

\section{Uji Normalitas}

Dari proses pengujian normalitas yang telah dilakukan diperoleh ringkasan hasil seperti yang terlihat pada Tabel 4 berikut ini:

\section{Tabel 4}

Hasil Pengujian Normalitas

\begin{tabular}{|l|c|c|c|}
\hline \multicolumn{1}{|c|}{ Variabel } & Asymp Sig & Alpha $(\alpha)$ & Kesimpulan \\
\hline Kepercayaan $\left(\mathrm{X}_{1}\right)$ & 0,054 & 0,05 & Normal \\
\hline Kepuasan $\left(\mathrm{X}_{2}\right)$ & 0,094 & 0,05 & Normal \\
\hline Komitmen $\left(\mathrm{X}_{3}\right)$ & 0,185 & 0,05 & Normal \\
\hline Loyalitas Nasabah $(\mathrm{Y})$ & 0,175 & 0,05 & Normal \\
\hline
\end{tabular}

Sumber: Olahan Data SPSS, 2017

Berdasarkan Tabel 4 dapat dilihat hasil pengujian yang menunjukan bahwa data terdistribusi secara normal, karena nilai Asymp Sig kesemua variabel lebih besar dari Alpha $(0,05)$. Hal ini menunjukkan bahwa data terdistribusi secara normal.

\section{Uji Heteroskedastisitas}

Hasil pengujian Heteroskedas tisitas dapat dilihat pada Tabel 5 berikut ini: 
Tabel 5

Hasil Uji Heteroskedastisitas

\begin{tabular}{|l|c|c|c|}
\hline \multicolumn{1}{|c|}{ Variabel } & Sig. & Alpha $(\alpha)$ & Keterangan \\
\hline Kepercayaan $\left(\mathrm{X}_{1}\right)$ & 1,000 & 0,05 & Tidak terjadi Heteroskedastisitas \\
\hline Kepuasan $\left(\mathrm{X}_{2}\right)$ & 1,000 & 0,05 & Tidak terjadi Heteroskedastisitas \\
\hline Komitmen $\left(\mathrm{X}_{3}\right)$ & 1,000 & 0,05 & Tidak terjadi Heteroskedastisitas \\
\hline
\end{tabular}

Sumber: Olahan Data SPSS, 2017.

Dari Tabel 5 terlihat bahwa nilai signifikansi untuk semua variable lebih besar dari alpha $(0,05)$, tidak satupun variable bebas yang memiliki nilai signifikansi lebih kecil dari 0,05. Berdasarkan uraian tersebut, dapat disimpulkan bahwa tidak terjadi gejala Heteroskedas tisitas dalam penelitian ini.

Uji Multikolinieritas

Hasil pengujian multikoli nieritas dapat dilihat pada Tabel 6 berikut ini:

Tabel 6

Hasil Uji Multikolinieritas

\begin{tabular}{|l|c|c|c|}
\hline \multirow{2}{*}{ Variabel } & \multicolumn{2}{|c|}{ Collinearity Statistics } & \multirow{2}{*}{ Keterangan } \\
\cline { 2 - 3 } & Tolerance & VIF & Tidak ada multikolinieritas \\
\hline Kepercayaan $\left(\mathrm{X}_{1}\right)$ & 0,960 & 1,042 & Tidak ada multikolinieritas \\
\hline Kepuasan $\left(\mathrm{X}_{2}\right)$ & 0,685 & 1,459 & Tidak ada multikolinieritas \\
\hline Komitmen $\left(\mathrm{X}_{3}\right)$ & 0,703 & 1,423 & \multirow{2}{*}{} \\
\hline
\end{tabular}

Sumber: Olahan Data SPSS, 2017.

Dari Tabel 6 terlihat bahwa nilai tolerance untuk semua variabel independen tidak satupun yang memiliki nilai tolerance lebih kecil dari 0,10 dan begitu juga dengan nilai VIF, tidak satupun variabel bebas yang memiliki nilai VIF lebih besar dari 10. Berdasarkan uraian tersebut, dapat disimpulkan bahwa tidak terdapat multikolinieritas atau antara sesama variable bebas dalam penelitian ini tidak saling mempenga ruhi satu sama lain.

\section{Hasil Analisis Regresi Linier Berganda}

Hasil analisis regresi linier berganda dapat diringkas pada Tabel 7 berikut ini:

Tabel 7

Ringkasan Hasil Analisis Regresi Linier Berganda

\begin{tabular}{|c|l|c|}
\hline \multicolumn{1}{|c|}{ Variabel Terikat } & Konstanta danVariabel Bebas & Koefisien Regresi \\
\hline Loyalitas Nasabah $(\mathrm{Y})$ & Konstanta $(\mathrm{a})$ & 0,406 \\
\cline { 2 - 3 } & Kepercayaan $\left(\mathrm{X}_{1}\right)$ & 0,182 \\
\cline { 2 - 3 } & Kepuasan $\left(\mathrm{X}_{2}\right)$ & 0,330 \\
\cline { 2 - 3 } & Komitmen $\left(\mathrm{X}_{3}\right)$ & 0,339 \\
\hline
\end{tabular}

Sumber: Olahan Data SPSS 2017.

Berdasarkan hasil analisis regresi linier berganda yang disajikan pada

Tabel 7 di atas, berikut ini dapat dikemukakan persamaan regresi linier berganda:

$\mathrm{Y}=0,406+0,182 \mathrm{X}_{1}+0,330 \mathrm{X}_{2}+0,339 \mathrm{X}_{3}$

\section{Hasil Pengujian Hipotesis}

\section{Uji F Statistik}

Dari hasil olahan data dapat diketahui hasil uji F Statistik pada tabel 8 sebagai berikut: 
Tabel 8

Uji F Statistik

ANOVA $^{\text {D }}$

\begin{tabular}{|l|r|r|r|r|r|}
\hline Model & Sum of Squares & df & Mean Square & F & Sig. \\
\hline 1 Regression & 13.960 & 3 & 4.653 & 16.424 & $.000^{\mathrm{a}}$ \\
Residual & 27.200 & 96 & .283 & & \\
Total & 41.160 & 99 & & & \\
\hline
\end{tabular}

a. Predictors: (Constant), Komitmen, Kepercayaan, Kepuasan

b. Dependent Variable:

Loyalitas Nasabah

Sumber: Olahan Data SPSS 2017.

Berdarkan pengujian statistik dengan metode uji $\mathrm{F}$, di mana tingkat signifikan yang diperoleh lebih kecil yakni sebesar 0,000 dari standar signifikan yakni $5 \%$ atau 0,05 dan perbandingan antara $\mathrm{F}$ hitung dan $\mathrm{F}$ tabel, di mana $\mathrm{F}$ hitung sebesar 16,424 lebih besar dari F tabel yakni 2,47, maka dapat disimpulkan bahwa kepercayaan, kepuasan dan komitmen secara simultan atau bersama-sama memiliki pengaruh yang signifikan terhadap loyalitas nasabah.

\section{Uji t Statistik}

Dari proses pengujian telah diperoleh hasil seperti terlihat pada Tabel 9 sebagai berikut:

\section{Tabel 9}

Hasil Pengujian Hipotesis

\begin{tabular}{|l|c|c|c|c|c|}
\hline \multicolumn{1}{|c|}{ Variabel Bebas } & T Hitung & T Tabel & Sig. & Alpha & Kesimpulan \\
\hline Kepercayaan $\left(\mathrm{X}_{1}\right)$ & 1,545 & 1,665 & 0,126 & 0,05 & H1 Ditolak \\
\hline Kepuasan $\left(\mathrm{X}_{2}\right)$ & 3,014 & 1,665 & 0,003 & 0,05 & H2 Diterima \\
\hline Komitmen $\left(\mathrm{X}_{3}\right)$ & 3,202 & 1,665 & 0,002 & 0,05 & H3 Diterima \\
\hline
\end{tabular}

Sumber: Olahan Data SPSS 2017.

Kepercayaan tidak berpengaruh terhadap loyalitas nasabah tabungan taplus pada PT. Bank Negara Indonesia (Persero) Tbk. Cabang Rengat. Kepercayaan memiliki nilai signifikansi sebesar 0,126 , nilai signifikan tersebut lebih besar dari alpha 0,05 .

Kepuasan berpengaruh positif dan signifikan terhadap loyalitas nasabah tabungan taplus pada PT. Bank Negara Indonesia (Persero) Tbk. Cabang Rengat. Kepuasan memiliki nilai signifikansi sebesar 0,003, nilai signifikan tersebut lebih kecil dari alpha 0,05 .

Komitmen berpengaruh positif dan signifikan terhadap loyalitas nasabah tabungan taplus pada PT. Bank Negara Indonesia (Persero) Tbk. Cabang Rengat. Komitmen memiliki nilai signifikansi sebesar 0,002, nilai signifikan tersebut lebih kecil dari alpha 0,05 .

\section{Uji Koefisien Determinasi}

Dari proses pengujian koefisien determinasi yang telah dilakukan diperoleh ringkasan hasil seperti yang terlihat pada Tabel 10 berikut ini: 


\section{Tabel 10}

Hasil Pengujian Koefisien Determinasi

Model Summary

\begin{tabular}{|l|r|r|r|r|r|}
\hline Model & $\mathrm{R}$ & $\mathrm{R}$ Square & \multicolumn{1}{|c|}{$\begin{array}{c}\text { Adjusted } \mathrm{R} \\
\text { Square }\end{array}$} & $\begin{array}{c}\text { Std. Error of the } \\
\text { Estimate }\end{array}$ & \multicolumn{1}{c|}{ Durbin-Watson } \\
\hline 1 & $.582^{\mathrm{a}}$ & .339 & .319 & .53229 & 2.260 \\
\hline
\end{tabular}

a. Predictors: (Constant), Komitmen, Kepercayaan, Kepuasan

b. Dependent

Variable: Loyalitas

Nasabah

Sumber: Olahan Data SPSS 2017.

Dari hasil olahan data yang dapat dilihat pada Tabel 10, diketahui bahwa dari pengujian Koefisien Determinasi terlihat nilai Adjusted $R$ square adalah sebesar 0,319 atau sama dengan 31,9\%. Hasil tersebut memperlihatkan bahwa loyalitas nasabah tabungan taplus pada PT. Bank Negara Indonesia (Persero) Tbk. Cabang Rengat yang dapat dijelaskan oleh kepercayaan, kepuasan, dan komitmen sebesar $31,9 \%$.

\section{Pembahasan}

\section{Pengaruh Kepercayaan Terhadap Loyalitas Nasabah}

Berdasarkan pada tabel 4.9 yang telah disajikan untuk hipotesis pertama didapatkan hasil estimasi variabel kepercayaan memiliki nilai signifikansi 0,126. Nilai signifikansi tersebut besar dari $\alpha=0,05$ yang menunjukkan bahwa variabel kepercayaan tidak berpengaruh terhadap loyalitas nasabah.

Sejalan dengan konteks relationship marketing, kepercayaan akan berpengaruh terhadap loyalitas, hal ini dikarenakan kepercayaan menimbulkan suatu hubungan timbal balik yang bernilai sangat tinggi. Jadi dapat dikatakan bahwa loyalitas adalah suatu proses yang berkesinam bungan sebagai akibat dari terbentuk nya kepercayaan pelanggan (Morgan dan Hunt, 1994 dalam Ellena, 2011:22).

Hasil penelitian ini tidak sejalan dengan penelitian yang dilakukan oleh Ruben (2015) tentang Pengaruh Kualitas Layanan, Kepuasan Relasi, Kepercayaan, Dan Komitmen Terhadap Loyalitas Bisnis PT. Mitra Plastindo Mas Di Sidoarjo. Hasil penelitian menunjukkan bahwa kepuasan relasi, komitmen, serta kepercayaan, berpengaruh positif terhadap loyalitas bisnisPT. Mitra Plastindo Mas Di Sidoarjo.

\section{Pengaruh Kepuasan Terhadap Loyalitas Nasabah}

Berdasarkan pada tabel 4.24 yang telah disajikan untuk hipotesis kedua didapatkan hasil estimasi variabel kepuasan memiliki nilai signifikansi 0,003. Nilai signifikansi tersebut kecil dari $\alpha=0,05$ yang menunjukkan bahwa variabel kepuasan berpengaruh positif dan signifikan terhadap loyalitas nasabah.

Menurut Kotler dan Keller (2009:14) kepuasan mencerminkan penilaian seseorang tentang kinerja produk anggapannya atau hasil kaitannya dalam ekspektasi. Jika kinerja produk tersebut tidak memenuhi ekspektasi, pelanggan tersebut tidak puas dan kecewa. Jika kinerja produk sesuai dengan ekspektasi, pelanggan tersebut puas. Jika kinerja produk melebihi ekspektasi, pelanggan tersebut senang. 
Hasil penelitian ini sejalan dengan penelitian yang dilakukan oleh Maria (2014) tentang Pengaruh Kepuasan Nasabah Terhadap Loyalitas Nasabah KPR BTN Pada PT. Bank Tabungan Negara Tbk. Cabang Padang. Dari hasil penelitian dan penganalisaan data yang telah dilakukan maka dapatlah diketahui kepuasan nasabah KPR BTN berpengaruh positif terhadap loyalitas pada PT. Bank Tabungan Negara Tbk. Cabang Padang.

\section{Pengaruh Komitmen Terhadap Loyalitas Nasabah}

Berdasarkan pada tabel 4.24 yang telah disajikan untuk hipotesis ketiga didapatkan hasil estimasi variabel komitmen memiliki nilai signifikansi 0,002. Nilai signifikansi tersebut kecil dari $\alpha=0,05$ yang menunjukkan bahwa variabel komitmen berpengaruh positif dan signifikan terhadap loyalitas nasabah.

Barnes (2003:150) menyata kan bahwa komitmen adalah suatu keadaan psikologis yang secara global mewakili pengalaman ketergantungan pada suatu hubungan; komitmen meringkas pengalaman ketergantung an sebelumnya dan mengarahkan reaksi pada situasi baru. Komitmen merupakan orientasi jangka panjang dalam suatu hubungan, termasuk keinginan untuk mempertahankan hubungan itu. Bagi bisnis yang menghadapi tingkat persaingan yang tinggi, hal ini mengimplikasikan bahwa kemam puan perusahaan untuk menciptakan hubungan yang tahan lama dengan pelanggan tidak hanya ditentukan oleh aksi perusahaan itu sendiri, melainkan juga oleh aksi para pesaingnya.

Hasil penelitian ini sejalan dengan penelitian yang dilakukan oleh Zulia (2015) tentang Pengaruh Citra Merek, Kepuasan, Kepercayaan Dan Komitmen Terhadap Loyalitas Nasabah Bank Tabungan Pensiunan Nasional (BTPN) Semarang (Studi Pada BTPN Pedurungan Semarang). Hasil penelitian menunjukkan bahwa citra merek, kepuasan, kepercayaan, dan komitmen berpengaruh positif dan signifikan terhadap loyalitas nasabah.

\section{SIMPULAN}

1. Kepercayaan tidak berpengaruh terhadap loyalitas nasabah tabungan taplus pada PT. Bank Negara Indonesia (Persero) Tbk. Cabang Rengat. Kepercayaan memiliki nilai signifikansi sebesar 0,126 , nilai signifikan tersebut lebih besar dari alpha 0,05 .

2. Kepuasan berpengaruh positif dan signifikan terhadap loyalitas nasabah tabungan taplus pada PT. Bank Negara Indonesia (Persero) Tbk. Cabang Rengat. Kepuasan memiliki nilai signifikansi sebesar 0,003, nilai signifikan tersebut lebih kecil dari alpha 0,05.

3. Komitmen berpengaruh positif dan signifikan terhadap loyalitas nasabah tabungan taplus pada PT. Bank Negara Indonesia (Persero) Tbk. Cabang Rengat. Komitmen memiliki nilai signifikansi sebesar 0,002, nilai signifikan tersebut lebih kecil dari alpha 0,05.

\section{DAFTAR PUSTAKA}

Affandi, Lutfi. 2011. "Pengaruh Komitmen Relasi, Kualitas Layanan, Dan Kepercayaan Terhadap Loyalitas Konsumen (Studi Pada Pt. Teduh Makmur Semarang)". Fakultas Ekonomi Universitas Diponegoro. Semarang. 
Aziz, N. (2019). Pengaruh Komunikasi Efektif Terhadap Kepuasan Pelayanan Rumah Sakit Islam Siti Rahmah Padang. https://doi.org/10.17605/OSF.IO/T2H7Y

Aziz, N. (2019). Pengaruh Kualitas Layanan Terhadap Kepuasan Nasabah SMS Banking Pada Bank Nagari Cabang Pembantu RSUP DR M Djamil Padang. https://doi.org/10.17605/OSF.IO/S3JVG

Barnes, James G., 2003. Secrets Of Customer Relationship Management, ANDI, Yogyakarta

Fernandes, Y. D., \& Marlius, D. (2018). Peranan Customer Service Dalam Meningkatkan Pelayanan Kepada Nasabah Pada PT. Bank Pembangunan Daerah Sumatera Barat Cabang Utama Padang. https://doi.org/10.31227/osf.io/wrh3p

Fernos, J., \& Putra, Y. E. (2019). Analisa Pengaruh Kualitas Pelayanan Terhadap Kepuasan Nasabah Pada PT. Bank Mega Syari'ah Padang. https://doi.org/10.31219/osf.io/y2baf

Fitri Ningtyas dan Basuki Rachmad. 2011. Pengaruh Kepercayaan, Komitmen, Komunikasi, Penanganan Masalah Dan Kepuasan Nasabah Terhadap Loyalitas Nasabah Bank Muamalat Di Surabaya. Journal Of Business And Banking Volume 1, No. 1, May 2011, Pages $51-60$.

Griffin, Jill. 2003. Customer Loyalty:Menumbuhkan Dan. Mempertahankan Pelanggan. Jakarta

Kotler, Philip dan Keller, Kevin, L. 2009. Manajemen Pemasaran. Erlangga: Jakarta.

Maria Magdalena. 2014. Pengaruh Kepuasan Nasabah Terhadap Loyalitas Nasabah Kpr Btn Pada Pt. Bank Tabungan Negara Tbk. Cabang Padang. Jurnal Kbp. Vol 2 - No. 2, Juni 2014.

Marlius, D. (2018). Pengaruh Dimensi Kualitas Pelayanan Website Akademik Terhadap Kepuasan Mahasiswa Pada STIE “KBP”. Jurnal Ipteks Terapan. $\begin{array}{lllll}\text { Volume } & 12 . & \text { No. } & \text { Hal. } & \text { 116-128. }\end{array}$ http://doi.org/10.22216/jit.2018.v12i2.633

Mowen, Jhon.C dan Minor, M. 2002. Perilaku Konsumen. Jilid 2, Edisi Kelima. Jakarta: Erlangga.

Mulyadi, H., \& Susanti, F. (2018). Pengaruh Penerapan Strategi Customer Relationship Marketing Terhadap Kepuasan Nasabah Pada PT. Pro Car 
International

Finance

https://doi.org/10.31227/osf.io/bhq8d

Cabang

Padang.

Putra, Y. E., \& Aziz, N. (2019). Pengaruh Kualitas Pelayanan Dan Kepuasan Pelanggan Terhadap Loyalitas Nasabah PT. Bank Rakyat Indonesia Cabang Padang. https://doi.org/10.31219/osf.io/hcsw2

Safitri, R. N., \& Marlius, D. (2017). Penerapan E-Banking Dalam Meningkatkan Jasa Dan Layanan Perbankan Di PT. Bank Rakyat Indonesia Cabang Padang. https://doi.org/10.31227/osf.io/gkv8t

Sekaran, Uma. 2006. Research Methods For Business, Edisi Keempat. Salemba Empat: Jakarta

Susanti, F. W Ekazaputri. (2018). Service Performance Dan Kepuasan Sebagai Moderating Variabel Terhadap Loyalitas Nasabah Pada PT BPR Labuh Gunung Payakumbuh Jurnal Benefita: Ekonomi Pembangunan Manajemen Bisnis Dan Akuntansi. Volume 3. No. 3. Hal. 433444.http://doi.org/10.22216/jbe.v3i3.3472

Tiza, M. F., \& Susanti, F. (2019). Pengaruh Kualitas Pelayanan Terhadap Kepuasan Pelanggan, Studi kasus pada perusahaan JNE Cabang Padang. https://doi.org/10.31227/osf.io/hx87m

Ulfa, M., \& Mayliza, R. (2019). Pengaruh Kualitas Pelayanan Dan Kepuasan Pelanggan Terhadap Loyalitas Pelanggan PDAM Kota Padang. https://doi.org/10.31219/osf.io/spmgv

Zulia Prastiwi. 2015. Pengaruh Citra Merek, Kepuasan, Kepercayaan Dan Komitmen Terhadap Loyalitas Nasabah Bank Tabungan Pensiunan Nasional (Btpn) Semarang (Studi Pada Bptn Pedurungan Semarang). Progam Study Manajemen - S1, Fakultas Ekonomi \& Bisnis, Universitas Dian Nuswantoro Semarang. 